\title{
UJI BEBERAPA KONSENTRASI EKSTRAK KULIT JENGKOL (Pithecellobium lobatum Benth) UNTUK MENGENDALIKAN ULAT DAUN BAWANG (Spodoptera exigua Hubner)
}

\section{Test Some Concentration of Jengkol Rind (Pithecellobium lobatum Benth) Extract to Control Beet Armyworm (Spodoptera exigua Hubner)}

\author{
Divasyah Luthfi Nasution ${ }^{1}$, Rusli Rustam*1 \\ ${ }^{1}$ Jurusan Agroteknologi Fakultas Pertanian Universtias Riau Kampus Bina Widya Km. 12,5 \\ Simpang Baru Pekanbaru (28293) \\ e-mail : rusli69@yahoo.co.id
}

\begin{abstract}
Beet armyworm (Spodoptera exigua Hubner) is one of the main problems in shallot cultivation which can cause production losses of up to $100 \%$ if not controlled. The use of botanical pesticides from jengkol rind extract (Pithecellobium lobatum Benth) is a solution to control beet armyworms (Spodoptera exigua Hubner). This study aims to obtain a concentration of jengkol rind extract which is effective to controlling beet armyworm. The study was conducted at the Laboratory of Plant Pest and Experimental Garden at the Faculty of Agriculture, University of Riau from January until March 2020. This research was conducted experimentally using a completely randomized design (CRD) with five treatments and four replications. The treatments given were jengkol rind extract concentration $0 \mathrm{~g} . \mathrm{l}^{-1}$ water, $25 \mathrm{~g} . \mathrm{l}^{-1}$ water, $50 \mathrm{~g} . \mathrm{l}^{-1}$ water, $75 \mathrm{~g} . \mathrm{l}^{-1}$ water and $100 \mathrm{~g} . \mathrm{l}^{-1}$ water. The results indicate that the application of jengkol rind extract $100 \mathrm{gl}^{-1}$ water is an effective concentration to control beet armyworm with an initial time of death 12.75 hours, a lethal time 50 at 37.50 hours, the highest daily mortality on the second day at $37.5 \%$ and total mortality is $92.5 \%$ in the 5 days after application.
\end{abstract}

Keywords: Pithecellobium lobatum Benth, Spodoptera exigua Hubner, botanical pesticide.

\section{PENDAHULUAN}

Bawang merah (Allium ascalonicum Linn) merupakan salah satu tanaman hortikultura unggulan yang telah lama diusahakan oleh petani secara intensif karena memiliki nilai ekonomis tinggi dan termasuk ke dalam kelompok rempah-rempah yang bermanfaat sebagai bumbu penyedap makanan. Tanaman bawang merah tersebar di berbagai provinsi di Indonesia. Provinsi penghasil utama terbesar bawang merah adalah Jawa Barat, Jawa Tengah, DI Yogyakarta, Jawa Timur, Sumatera Utara, Sumatera Barat, Bali, NTB dan Sulawesi Selatan (Dewi, 2012).
Provinsi Riau merupakan salah satu provinsi yang mengembangkan budidaya tanaman bawang merah untuk memenuhi kebutuhan daerahnya.

Provinsi Riau sejak tahun 2014 hingga tahun 2017 mengalami peningkatan dan penurunan produksi bawang merah. Produksi tanaman bawang merah meningkat pada tahun 2015 yaitu menjadi 140 ton dari 59 ton pada tahun 2014. Produksi tanaman bawang merah pada tahun 2016 mengalami peningkatan menjadi 303 ton, dan pada tahun 2017 produksi tanaman bawang merah di Riau turun menjadi 263 ton (Kementrian Pertanian 
Republik Indonesia, 2017). Salah satu penyebab menurunnya produksi bawang merah adanya serangan organisme pengganggu tanamanan.

Organisme pengganggu tanaman yang menjadi masalah utama dalam budidaya bawang merah adalah serangan hama Spodoptera exigua Hubner (Moekasan et al., 2012). S. exigua menyerang tanaman bawang merah sejak fase vegetatif hingga panen. Rukmana (1994) menyatakan bahwa S. exigua merusak tanaman bawang dengan cara membuat lubang pada bagian ujung daun sebagai jalan masuk ulat, lalu memakan daun bagian dalam dengan menyisakan bagian epidermisnya saja sehingga daun terlihat bercak-bercak berwarna putih dan tembus cahaya bila diterawang. Setiawati et al. (2014) melaporkan bahwa serangan $S$. exigua dapat menyebabkan kehilangan hasil pada tanaman bawang merah sebesar 34\%-54\%. Negara (2003) menyatakan serangan $S$. exigua dapat menyebabkan kehilangan hasil hingga 100\% jika tidak dikendalikan. Hama S. exigua harus dikendalikan untuk menyelamatkan produksi bawang merah.

$$
\text { Suryaminarsih et al. }
$$
menyatakan bahwa untuk menekan serangan hama dalam budidaya tanaman, dianjurkan menggunakan pestisida nabati karena pestisida kimia dapat menyebabkan terjadinya resistensi, resurjensi, kemunculan hama sekunder, terbunuhnya musuh alami, penumpukan residu pada hasil panen, menimbulkan gangguan kesehatan bagi manusia dan mencemari lingkungan. Tanaman yang berpotensi sebagai pestisida nabati adalah tanaman jengkol (Pithecellobium lobatum Benth).

Jengkol merupakan tanaman khas dari wilayah Asia Tenggara khususnya di Indonesia yang telah tersebar di berbagai wilayah Indonesia baik yang tumbuh secara liar maupun yang dibudidayakan oleh para petani (Hutauruk, 2010). Tanaman jengkol memiliki senyawa kimia khas yang bernama asam jengkolat (Ambarningrum et al., 2007). Kulit jengkol mengandung senyawa kimia alkaloid, triterpenoid, saponin, flavonoid, tanin dan asam jengkolat sehingga dapat dimanfaatkan sebagai pestisida nabati (Astuti, 2013). Alkaloid merupakan racun kontak dan perut yang bekerja dengan mengganggu saluran pencernaan dan sistem saraf larva (Yuantari, 2009 dalam Ahdiyah dan Purwani, 2015). Saponin merupakan kelompok triterpenoid yang bekerja dengan menurunkan enzim protease dalam saluran makanan serangga serta mengganggu penyerapan makanan (Gershenzon dan Croteau, 1991 dalam Ambarningrum et al., 2007). Flavonoid pada kulit jengkol bersifat racun perut dan antifeedant, sehingga akan berpengaruh terhadap daya makan larva dan aktivitas makan larva terhambat (Azlansah et al., 2019). Tanin merupakan racun perut yang bekerja dengan menghalangi serangga dalam mencerna makanan dan menyebabkan sedikitnya makanan yang dikonsumsi serangga (Howe et al., 1988 dalam Pradani, 2009). Asam jengkolat merupakan asam amino alifatik yang mengandung sulfur dan bersifat toksik (Ambarningrum et al., 2007). 
Beberapa penelitian mengenai pestisida nabati kulit jengkol telah dilakukan. Hasil penelitian pestisida ekstrak kulit jengkol yang dilakukan oleh Azlansah et al. (2019) terhadap larva Spodoptera litura menunjukkan bahwa ekstrak kulit jengkol berpengaruh terhadap mortalitas larva $S$. litura pada daun sawi dengan mortalitas larva mencapai $85 \%$ pada 5 hari setelah aplikasi menggunakan konsentrasi $10 \%$ ekstrak kulit jengkol. Hal ini menunjukkan bahwa ekstrak kulit jengkol efektif dalam mengendalikan hama larva $S$. litura karena menurut Dadang dan Prijono (2008) pestisida nabati dikatakan efektif apabila mampu mematikan $80 \%$ populasi hama pada konsentrasi maksimal 10\% dengan pelarut air. Penelitian ini bertujuan untuk mendapatkan konsentrasi ekstrak kulit jengkol (Pithecellobium lobatum Benth) yang efektif untuk mengendalikan ulat daun bawang (Spodoptera exigua Hubner).

\section{METODE PENELITIAN}

Penelitian dilakukan di Laboratorium Hama Tumbuhan Fakultas Pertanian Universitas Riau dan Kebun Percobaan Fakultas Pertanian Universitas Riau Kampus Bina Widya KM 12,5, Pekanbaru. Penelitian dilaksanakan dari bulan Januari hingga Maret 2020.

Alat yang digunakan dalam penelitian adalah polybag ukuran $25 \mathrm{~cm}$ x $30 \mathrm{~cm}$, stoples plastik berukuran $8 \mathrm{~cm} \times 5 \mathrm{~cm}$, stoples plastik berukuran $22 \mathrm{~cm}$ x $20 \mathrm{~cm}$, sekop kecil, karet gelang, kain kassa, sungkup tanaman bawang merah, cangkul, batang pengaduk, pinset, kawat, gembor, kapas, gelas beaker, gelas ukur, termohygrometer, timbangan analitik, blender, hand sprayer $50 \mathrm{ml}$, kertas label, benang, gunting, saringan, alat tulis, dan kamera.

Bahan yang digunakan dalam penelitian adalah larva S. exigua instar III, kulit jengkol, sabun krim, aquades, serbuk gergaji, daun bawang, madu, tanah, umbi bawang merah dan pupuk kandang ayam.

Penelitian dilakukan secara eksperimen dengan menggunakan rancangan acak lengkap (RAL) yang terdiri atas lima konsentrasi, setiap perlakuan diulang sebanyak empat kali sehingga diperoleh 20 unit percobaan. Setiap unit percobaan terdiri atas 10 ekor larva $S$. exigua instar III. Perlakuan yang diberikan adalah konsentrasi ekstrak kulit jengkol 0 g. $1^{-1}$ air, 25 g. $1^{-1}$ air, 50 g. $l^{-1}$ air, 75 g. $1^{-1}$ air, dan 100 g. $1^{-1}$ air.

Data mortalitas harian yang diperoleh dari hasil penelitian ditampilkan dalam bentuk grafik dan dianalisis secara deskriptif. Data lethal concentration $\left(\mathrm{LC}_{50}\right.$ dan $\mathrm{LC}_{95}$ ) dianalisis probit menggunakan program POLO-PC. Data waktu awal kematian, mortalitas total, dan lethal time 50 dianalisis secara statistik dengan menggunakan sidik ragam. Data hasil sidik ragam diuji lanjut dengan uji beda nyata terkecil (BNT) pada taraf 5\%.

\section{HASIL DAN PEMBAHASAN}

\section{Waktu Awal Kematian}

Hasil sidik ragam menunjukkan bahwa perlakuan beberapa konsentrasi ekstrak kulit jengkol ( $P$. lobatum) memberikan pengaruh yang nyata terhadap waktu awal kematian larva S. exigua. Hasil rata-rata waktu awal 
kematian larva S. exigua setelah dilakukan uji BNT pada taraf 5\% dapat dilihat pada Tabel 1.

Tabel 1 menunjukkan bahwa pemberian konsentrasi ekstrak kulit jengkol 100 g. $1^{-1}$ air menyebabkan waktu awal kematian tercepat yaitu 12,75 jam setelah aplikasi dan berbeda tidak nyata dengan konsentrasi 75 g..$^{-1}$ air yaitu 18 jam. Hal ini dikarenakan semakin tinggi konsentrasi yang diberikan maka semakin banyak bahan aktif yang terkandung. Semakin banyak bahan aktif maka semakin tinggi daya racun yang akan mengakibatkan larva $S$. exigua lebih cepat mengalami kematian. Sitompul et al. (2014) menyatakan bahwa semakin tinggi konsentrasi yang digunakan maka efek racun juga semakin tinggi sehingga kematian serangga lebih cepat terjadi.

Perlakuan dengan konsentrasi 25 g. $1^{-1}$ air menyebabkan waktu awal kematian terlama yaitu 28,5 jam setelah aplikasi dan berbeda tidak nyata dengan konsentrasi 50 g. $\mathrm{l}^{-}$ ${ }^{1}$ air yaitu 24,75 , namun berbeda nyata dengan perlakuan lainnya. Hal ini disebabkan karena perlakuan ini merupakan konsentrasi ekstrak kulit jengkol paling rendah, sehingga bahan aktif yang terkandung di dalamnya sedikit. Menurut Harbone (1979) dalam Nursal et al. (1997), pemberian konsentrasi ekstrak yang rendah maka pengaruh yang ditimbulkan pada serangga akan semakin lama, disamping itu daya kerja pestisida nabati ditentukan oleh besarnya konsentrasi yang diberikan.

Pradani (2009) melaporkan bahwa senyawa alkaloid dan saponin merupakan bahan aktif yang paling banyak terkandung dalam ekstrak kulit jengkol. Yuantari (2009) dalam Ahdiyah dan Purwani (2015) menyatakan bahwa senyawa alkaloid dapat masuk ke dalam tubuh larva sebagai racun perut dan racun kontak. Alkaloid berupa garam sehingga dapat mendegradasi membran sel saluran pencernaan untuk masuk ke dalam dan merusak sel. Alkaloid juga dapat mengganggu sistem kerja saraf larva dengan menghambat kerja enzim asetilkolinesterase. Ambarningrum et al., (2009) menyatakan bahwa saponin dalam ekstrak kulit jengkol akan mengikat sterol dalam saluran pencernaan makanan larva sehingga dapat mengganggu proses pencernaan dan proses pergantian kulit serangga.

Tabel 1. Rata-rata waktu awal kematian larva S. exigua setelah pemberian beberapa konsentrasi ekstrak kulit jengkol (P. lobatum) (jam)

\begin{tabular}{cc}
\hline Konsentrasi ekstrak kulit jengkol & Waktu awal kematian S.exigua (jam) \\
\hline $0 \mathrm{~g} .1^{-1}$ air & $120,00 \mathrm{a}$ \\
$25 \mathrm{~g} .1^{-1}$ air & $28,50 \mathrm{~b}$ \\
$50 \mathrm{~g} .1^{-1}$ air & $24,75 \mathrm{bc}$ \\
$75 \mathrm{~g} .1^{-1}$ air & $18,00 \mathrm{~cd}$ \\
$100 \mathrm{~g} .1^{-1}$ air & $12,75 \mathrm{~d}$ \\
\hline
\end{tabular}

Angka-angka pada lajur yang diikuti oleh huruf kecil yang tidak sama berbeda nyata menurut uji BNT pada taraf $5 \%$ setelah ditransformasi dengan $\sqrt{y}$ 
Gejala awal kematian larva S. exigua ditandai dengan perubahan tingkah laku yaitu larva S. exigua menjadi kurang aktif bergerak, pergerakan lambat dan menurunnya aktifitas makan. Selain terjadi perubahan tingkah laku, juga terjadi perubahan morfologi, larva S. exigua yang mati ditandai dengan tubuhnya yang menjadi hitam, mengkerut, dan lunak.

\section{Lethal Time $50\left(\mathrm{LT}_{50}\right)$}

Hasil sidik ragam menunjukkan bahwa perlakuan beberapa konsentrasi ekstrak kulit jengkol ( $P$. lobatum) memberikan pengaruh yang nyata terhadap lethal time $50\left(\mathrm{LT}_{50}\right)$ S. exigua. Hasil rata-rata Lethal time $50\left(\mathrm{LT}_{50}\right)$ S. exigua setelah dilakukan uji BNT pada taraf 5\% dapat dilihat pada Tabel 2.

Tabel 2 menunjukkan bahwa pemberian perlakuan konsentrasi ekstrak kulit jengkol 100 g.l ${ }^{-1}$ air menyebabkan waktu paling cepat untuk mematikan $50 \%$ larva $S$. exigua yaitu pada 37,50 jam setelah aplikasi berbeda nyata dengan perlakuan lainnya. Hal ini berbeda dengan hasil waktu awal kematian pada Tabel 1 yang menunjukkan bahwa konsentrasi ekstrak kulit jengkol 100 g.1 ${ }^{-1}$ air menyebabkan waktu awal kematian larva $S$. exigua tercepat pada 12,75 jam setelah aplikasi berbeda tidak nyata dengan konsentrasi 75 g.l1 air dengan waktu awal kematian pada 18,00 jam setelah aplikasi. Hal ini diduga karena pada pengamatan $\mathrm{LT}_{50}$ bahan aktif yang terkandung dalam kulit jengkol sudah terakumulasi dengan baik di dalam tubuh larva S. exigua sehingga sudah dapat bekerja secara maksimal dan memberikan hasil yang berbeda.

Tabel 2. Rata-rata Lethal time $50\left(\mathrm{LT}_{50}\right)$ larva S. exigua setelah pemberian beberapa konsentrasi ekstrak kulit jengkol (P. lobatum) (jam)

\begin{tabular}{cc}
\hline Konsentrasi ekstrak kulit jengkol & Lethal time $50 \quad$ S. exigua (jam) \\
\hline $0 \mathrm{~g} .1^{-1}$ air & $120,00 \mathrm{a}$ \\
$25 \mathrm{~g} .1^{-1}$ air & $120,00 \mathrm{a}$ \\
$50 \mathrm{~g} .1^{-1}$ air & $108,75 \mathrm{a}$ \\
$75 \mathrm{~g} .1^{-1}$ air & $52,50 \mathrm{~b}$ \\
$100 \mathrm{~g} .1^{-1}$ air & $37,50 \mathrm{c}$ \\
\hline
\end{tabular}

Angka-angka pada lajur yang diikuti oleh huruf kecil yang tidak sama berbeda nyata menurut uji BNT pada taraf $5 \%$ setelah ditransformasi dengan $\sqrt{y}$

Tabel 1 dan 2 memperlihatkan bahwa jengkol yang masuk ke dalam tubuh larva konsentrasi ekstrak kulit jengkol $100 \mathrm{~g} . \mathrm{l}^{-1}$ air $S$. exigua semakin banyak sehingga dapat menunjukkan waktu awal kematian larva S. exigua tercepat pada 12,75 jam setelah aplikasi dan $\mathrm{LT}_{50}$ tercepat yaitu pada 37,50 jam setelah aplikasi. Hal ini terjadi karena konsentrasi $100 \mathrm{~g} .1^{-1}$ air merupakan konsentrasi tertinggi, pada pemberian konsentrasi yang tinggi senyawa racun dari ekstrak kulit mempercepat terjadinya kematian larva $S$. exigua dibandingkan perlakuan lainnya. Pendapat ini diperkuat oleh Muslihat dan Salbiah (2020) yang menyatakan bahwa pemberian konsentrasi ekstrak yang lebih tinggi dapat mempercepat waktu awal 
kematian dan waktu untuk mematikan 50\% larva.

Konsentrasi ekstrak kulit jengkol 50 g..$^{-1}$ air menyebabkan $\mathrm{LT}_{50}$ larva S. exigua pada 108,75 jam setelah aplikasi dan berbeda tidak nyata dengan konsentrasi 0 g. $1^{-1}$ air dan 25 g. $1^{-1}$ air yang tidak mampu mematikan 50\% larva S. exigua hingga akhir pengamatan (120 jam). Hal ini diduga karena larva $S$. exigua masih dapat mentolelir peningkatan konsentrasi bahan aktif yang terkandung dalam ekstrak kulit jengkol. Pernyataan tersebut didukung oleh Prijono (1999) yang menyatakan bahwa kepekaan suatu serangga terhadap senyawa bioaktif dapat disebabkan oleh kemampuan metabolik serangga yang dapat menguraikan bahan racun dari tubuhnya sehingga mampu mentolerir racun yang diberikan.

\section{Lethal Concentration ( $\mathrm{LC}_{50}$ dan $\mathrm{LC}_{95}$ )}

Berdasarkan hasil analisis probit lethal concentration (LC) menggunakan program POLO-PC, konsentrasi ekstrak kulit jengkol memperlihatkan $\mathrm{LC}_{50}$ dan $\mathrm{LC}_{95}$ yaitu berturutturut $4,94 \%$ dan $15,34 \%$. Hasil analisis probit dapat dilihat pada Tabel 3.

Tabel 3. Lethal concentration ektrak kulit jengkol $(P$. lobatum) terhadap larva $S$. exigua

\begin{tabular}{ccc}
\hline $\begin{array}{c}\text { Lethal } \\
\begin{array}{c}\text { concentration } \\
(\mathrm{LC})\end{array}\end{array}$ & $\begin{array}{c}\text { Konsentrasi } \\
(\%)\end{array}$ & $\begin{array}{c}\text { Kisaran } \\
\text { SK 95\% } \\
(\%)\end{array}$ \\
\hline $\mathrm{LC}_{50}$ & 4,94 & $(2,74-$ \\
& & $7,39)$ \\
$\mathrm{LC}_{95}$ & 15,34 & $(9,27-$ \\
& & $183,25)$ \\
\hline
\end{tabular}

Keterangan: SK= Selang Kepercayaan

\section{Mortalitas Harian}

Hasil pengamatan mortalitas harian larva $S$. exigua dengan perlakuan beberapa konsentrasi ekstrak kulit jengkol menunjukkan bahwa persentase kematian larva S. exigua mengalami fluktuasi dari hari pertama hingga hari kelima. Fluktuasi mortalitas harian larva S. exigua dapat dilihat pada Gambar 1.

Gambar 1 menunjukkan fluktuasi mortalitas harian larva $S$. exigua pada setiap perlakuan dari hari pertama pengamatan hingga hari kelima pengamatan. Pada hari pertama semua perlakuan telah menyebabkan kematian larva $S$. exigua pada kisaran 2,5-25\% kecuali pada perlakuan 0 g. $1^{-1}$ air. Puncak mortalitas larva S. exigua terjadi di hari kedua pada kisaran 15\%-37,5\%. Pada hari ketiga, keempat, dan kelima mortalitas larva S. exigua menurun yaitu pada kisaran berturut-turut $\quad 5 \%-22,5 \%, \quad 0 \%-5 \%, \quad$ dan $0 \%-2,5 \%$.

Hari pertama setelah perlakuan terlihat bahwa perlakuan 25 g..$^{-1}$ air menyebabkan mortalitas sebesar $2,5 \%$, perlakuan 50 g. $1^{-1}$ air menyebabkan mortalitas sebesar 5\%, perlakuan 75 g. $^{-1}$ air menyebabkan mortalitas sebesar $10 \%$, sedangkan pada perlakuan tertinggi yaitu 100 g. $^{-1}$ air menunjukkan mortalitas pada hari pertama sebesar $25 \%$. Perbedaan mortalitas harian larva S. exigua pada setiap perlakuan diduga karena kandungan bahan aktif pada setiap perlakuan ekstrak kulit jengkol berbeda, semakin tinggi konsentrasi yang diberikan maka semakin banyak bahan aktif yang masuk ke dalam tubuh larva S. exigua. Hal ini didukung oleh Yunianti (2016) bahwa mortalitas akan terjadi 
lebih cepat pada konsentrasi tinggi masuk ke dalam tubuh serangga dan begitu dikarenakan semakin banyak bahan aktif yang sebaliknya.

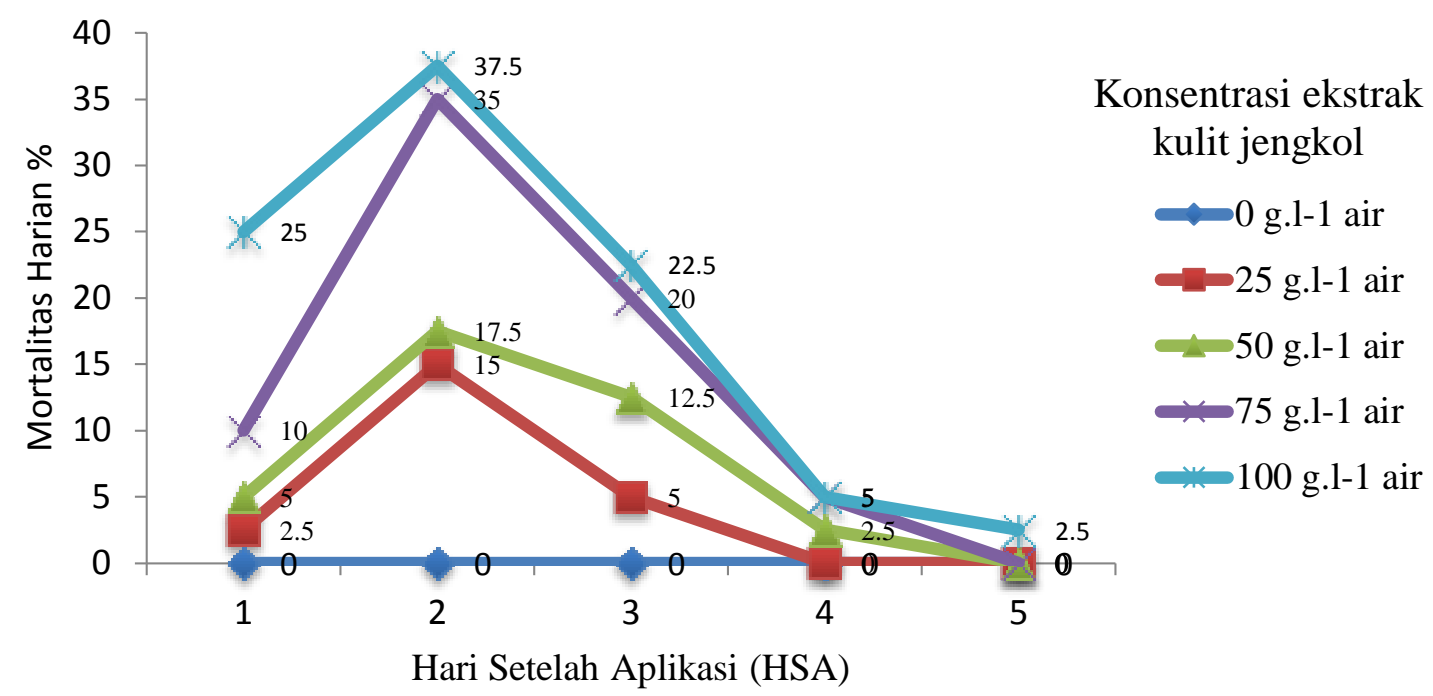

Gambar 1. Fluktuasi mortalitas harian larva S. exigua setelah aplikasi beberapa konsentrasi ekstrak kulit jengkol

Hari kedua setelah aplikasi merupakan puncak mortalitas larva S. exigua dengan kisaran 15\%-37,5\%. Mortalitas tertinggi terdapat pada perlakuan 100 g. $1^{-1}$ air yang menyebabkan kematian serangga uji sebesar 37,5\% diikuti perlakuan dengan konsentrasi 75 g. $1^{-1}$ air sebesar 35\%, konsentrasi 50 g. $\mathrm{l}^{-1}$ air sebesar $17,5 \%$ dan konsentrasi 25 g. $1^{-1}$ air sebesar 15\%. Hal ini disebabkan karena bahan aktif pada ekstrak kulit jengkol telah terakumulasi dalam tubuh larva $S$. exigua sehingga dapat bekerja secara maksimal. Hal ini sesuai dengan pendapat Tukimin dan Rizal (2002) yang menyatakan bahwa pestisida nabati pada umumnya akan bekerja secara maksimal pada 24 jam setelah aplikasi.

Faktor yang mempengaruhi kematian larva $S$. exigua pada setiap perlakuan disebabkan oleh bahan aktif alkaloid dan saponin yang ada di dalam kulit jengkol.
Setelah aplikasi ekstrak kulit jengkol tingkat konsumsi larva menurun dan kurang aktif bergerak sampai pada akhirnya larva $S$. exigua mengalami kematian. Ambarningrum et. al., (2007) melaporkan bahwa senyawa alkaloid yang terdapat dalam kulit jengkol menyebabkan mortalitas larva uji akibat larva tidak makan, sehingga larva mati dalam kondisi lemas. Selain itu, ekstrak kulit jengkol mampu menurunkan daya cerna larva uji dengan cara menghambat kerja enzim pencernaan sehingga pencernaan larva terganggu.

Hari ketiga, keempat, dan kelima terjadi penurunan mortalitas harian larva $S$. exigua. Hal ini disebabkan karena jumlah larva S. exigua uji semakin sedikit pada setiap perlakuan karena telah mengalami puncak mortalitas di hari kedua. Selain itu, penurunan mortalitas diduga terjadi karena telah 
terurainya bahan aktif dari ekstrak kulit jengkol yang diberikan pada perlakuan sehingga sudah tidak efektif dalam meracuni hama dan sulit menyebabkan kematian. Hal ini sesuai dengan pendapat Dadang dan Prijono (2008) yang menyatakan bahwa kekurangan dari pestisida nabati antara lain persistensi pestisida nabati rendah, sehingga bahan aktif yang terdapat pada pestisida nabati cepat terurai, bahkan memerlukan aplikasi lebih sering atau berulang-ulang agar populasi serangga uji menurun.

\section{Mortalitas Total}

Hasil sidik ragam menunjukkan bahwa perlakuan beberapa konsentrasi ekstrak kulit jengkol ( $P$. lobatum) memberikan pengaruh yang nyata terhadap mortalitas total larva S. exigua. Hasil rata-rata mortalitas total larva S. exigua setelah dilakukan uji BNT pada taraf 5\% dapat dilihat pada Tabel 4 .
Tabel 4 menunjukkan bahwa perlakuan beberapa konsentrasi ekstrak kulit jengkol memberikan pengaruh terhadap mortalitas total larva $S$. exigua hama tanaman bawang merah dengan kisaran 22,50\%-92,50\%. Konsentrasi 100 g..$^{-1}$ air menyebabkan persentase mortalitas tertinggi yaitu 92,5\% dan berbeda nyata dengan konsentrasi lainnya. Pemberian ekstrak kulit jengkol dengan konsentrasi 75 g..$^{-1}$ air mampu menyebabkan mortalitas total sebesar $70 \%$ dan berbeda nyata dengan konsentrasi lainnya. Pemberian ekstrak kulit jengkol dengan konsentrasi 50 g. l $^{-1}$ air menunjukkan persentase mortalitas total sebesar $37,5 \%$ dan berbeda tidak nyata dengan konsentrasi 25 g. $1^{-1}$ air dengan persentase mortalitas total $22,5 \%$ namun berbeda nyata dengan konsentrasi lainnya. Konsentrasi ekstrak kulit jengkol 0 g.l ${ }^{-1}$ air sampai akhir pengamatan (120) jam menunjukkan tidak ada larva $S$. exigua yang mati.

Tabel 4. Rata-rata mortalitas total larva $S$. exigua setelah pemberian beberapa konsentrasi ekstrak kulit jengkol ( $P$. lobatum) $(\%)$

$\begin{array}{cc}\text { Konsentrasi ekstrak kulit jengkol } & \text { Mortalitas total S. exigua }(\%) \\ 0 \mathrm{~g} .1^{-1} \text { air } & 0,00 \mathrm{a} \\ 25 \mathrm{~g} \cdot \mathrm{l}^{-1} \text { air } & 22,50 \mathrm{~b} \\ 50 \mathrm{~g} .1^{-1} \text { air } & 37,50 \mathrm{~b} \\ 75 \mathrm{~g} .1^{-1} \text { air } & 70,00 \mathrm{c} \\ 100 \mathrm{~g} .1^{-1} \text { air } & 92,50 \mathrm{~d}\end{array}$

Angka-angka pada lajur yang diikuti oleh huruf kecil yang tidak sama berbeda nyata menurut uji BNT pada taraf $5 \%$. Setelah ditransformasi dengan arcsin atau $\sin ^{-1} \sqrt{y}$

Aplikasi konsentrasi ekstrak kulit jengkol $100 \mathrm{~g} . \mathrm{l}^{-1}$ air menunjukkan persentase mortalitas tertinggi larva $S$. exigua yaitu 92,50\%. Hal ini disebabkan konsentrasi ekstrak kulit jengkol yang diberikan tinggi sehingga menyebabkan mortalitas total larva $S$. exigua semakin tinggi. Pernyataan ini sesuai dengan Azlansah et al. (2019) yang menyatakan bahwa tinggi rendahnya angka mortalitas pada larva S. litura tergantung 
pada kandungan bahan aktif dari ekstrak kulit jengkol.

Kemampuan ekstrak kulit jengkol dalam mematikan larva $S$. exigua dikarenakan kulit jengkol banyak mengandung senyawa alkaloid dan saponin. Pradani (2009) melaporkan bahwa ekstrak kulit jengkol mengandung senyawa alkaloid dan saponin yang sangat kuat, serta flavonoid dan terpenoid dengan kadar cukup dan tannin dengan kadar lemah. Senyawa dalam eksrak kulit jengkol mengakibatkan penghambatan makan larva sehingga menyebabkan kematian.

Senyawa alkaloid dan saponin yang terkandung pada ekstrak kulit jengkol masuk ke dalam tubuh larva $S$. exigua sebagai racun kontak dan racun perut, selanjutnya senyawa alkaloid akan bekerja sebagai racun saraf, racun pencernaan dan antifeedant, sedangkan senyawa saponin pada ekstrak kulit jengkol akan bekerja sebagai racun pencernaan. Ambarningrum et al. (2007) menyatakan senyawa alkaloid memiliki sifat toksik utama sebagai racun saraf. Selain itu, Pyenson (1980) dalam Azlansah et al. (2019) menyatakan senyawa alkaloid dapat menyebabkan iritasi pada saluran pencernaan larva dengan cara merusak membran peritrofik saluran pencernaan. Sari dan Armayanti (2018) menyatakan senyawa alkaloid memiliki rasa pahit sehingga dapat menurunkan aktivitas makan larva. Gershenzon dan Croteau (1991) dalam Ambarningrum et al. (2009) menyatakan bahwa senyawa saponin dapat menurunkan aktivitas enzim protease dalam saluran pencernaan makan serangga, sehingga mempengaruhi proses penyerapan makanan, akibatnya makanan yang masuk tidak dapat diserap dan langsung dikeluarkan dalam bentuk feses.

Pemberian ekstrak kulit jengkol efektif dalam mengendalikan larva $S$. exigua pada perlakuan 100 g. $1^{-1}$ air dengan mortalitas total mencapai 92,5\%. Hal ini sesuai dengan pernyataan Dadang dan Prijono (2008) bahwa pestisida nabati dikatakan efektif apabila mampu mematikan hama uji sebesar $80 \%$ dengan konsentrasi pestisida nabati yang diaplikasikan tidak melebihi $10 \%$ dengan pelarut air.

\section{KESIMPULAN}

1. Ekstrak kulit jengkol dengan konsentrasi 100 g. $1^{-1}$ air merupakan konsentrasi yang efektif untuk mengendalikan ulat daun bawang karena konsentrasi ini mampu menyebabkan mortalitas total sebesar 92,5\% dengan waktu awal kematian 12,75 jam setelah aplikasi dan lethal time 50 pada 37,50 jam setelah aplikasi.

2. Konsentrasi ekstrak kulit jengkol yang tepat untuk mematikan $50 \%$ ulat daun bawang adalah 4,94\% atau setara dengan 49,4 g. $1^{-1}$ air. Sementara itu konsentrasi yang tepat untuk mematikan 95\% ulat daun bawang adalah $15,34 \%$ atau setara dengan 153,4 g.1 ${ }^{-}$ 1 air.

\section{DAFTAR PUSTAKA}

Ahdiyah, I. dan K. I. Purwani, 2015, Pengaruh Ekstrak Daun Mangkokan (Nothopanax scutellarium) sebagai Larvasida Nyamuk 
Culex sp., Jurnal Sains dan Seni ITS. No.2, Vol. 4, Hal. 32-36.

Ambarningrum, T. B., Arthadi, H. Pratiknyo, dan S. Priyanto, 2007, Ekstrak Kulit Jengkol (Pithecellobium lobatum): Pengaruhnya sebagai Anti Makan dan terhadap Efisiensi Pemanfaatan Makanan Larva Instar $\mathrm{v}$ Heliothis armigera, Jurnal Sains MIPA, No. 3, Vol. 13, Hal. 165-170.

Ambarningrum, T. B., H. Pratiknyo, dan S. Priyanto, 2009, Indeks Nutrisi dan Kesintasan Larva Spodoptera litura F. yang Diberi Pakan Mengandung Ekstrak Kulit Jengkol (Pithecellobium lobatum Benth), Jurnal Hama Penyakit Tanaman Tropika, No. 2, Vol. 9, Hal. 109-114.

Astuti, P., 2013, Uji Efektifitas Kulit Buah Jengkol (Pithecolobium lobatum) terhadap Kematian Siput Murbei (Pomacea canaliculata), Ziraa'ah, No. 2, Vol. 37, Hal. 40-45.

Azlansah, A. Rusdy, dan Hasnah, 2019, Concentration Test of Jengkol Skin Extract against Armyworm Spodoptera litura F. at Laboratory, JIM Pertanian Unsyiah, No. 2, Vol. 4, Hal. 161-167.

Dadang dan D. Prijono, 2008, Insektisida Nabati: Prinsip, Pemanfaatan dan Pengembangan, Fakultas Pertanian Institut Pertanian Bogor, Bogor.

Dewi, N., 2012, Untung Segunung Bertanam Aneka Bawang, Pustaka Baru Press, Yogyakarta.

Hutauruk, J.E., 2010, Isolasi Senyawa Flavonida dari Kulit Buah Tumbuhan Jengkol (Pithecollobium lobatum Benth), Skripsi, Universitas Sumatera Utara, Medan.

Kementrian Pertanian Republik Indonesia, 2017, Statistik pertanian agricultural statistics 2017, Pusat Data dan Sistem
Informasi Pertanian Kementerian Pertanian Republik Indonesia, Jakarta.

Moekasan, T.K., R. S. Basuki, dan L. Prabaningrum, 2012, Penerapan Ambang Pengendalian Organisme Pengganggu Tumbuhan pada Budidaya Bawang Merah Dalam Upaya Mengurangi Penggunaan Pestisida, Jurnal Hortikultura, No. 1, Vol. 22, Hal. 47- 56.

Muslihat dan D. Salbiah, 2020. Uji Beberapa Konsentrasi Ekstrak Tepung Daun Bintaro (Cerbera manghas L.) terhadap Hama Penggerek Tongkol Jagung (Helicoperva armigera Hubner), Jurnal Dinamika Pertanian, No. 1, Vol. 36, Hal. 21-28.

Negara, A., 2003, Penggunaan Analisis Probit untuk Pendugaan Tingkat Kepekaan Populasi Spodoptera exigua terhadap Deltametrin di Daerah Istimewa Yogyakarta, Jurnal Informatika Pertanian, No. 1, Vol. 12, Hal. 1-9.

Nursal, E., Sudharto, P.S., dan R. Desmier, 1997, Pengaruh Konsentrasi Ekstrak Bahan Pestisda Nabati Terhadap Hama, Balai Penelitian Tanaman Obat, Bogor.

Pradani, F. Y, 2009, Indeks Pertumbuhan Larva Aedes aegypti L. yang Terdedah Dalam Ekstrak Air Kulit Jengkol (Pithecellobium lobatum), Aspirator, No. 2, Vol. 1, Hal. 81-86.

Rukmana, R., 1994, Bawang Merah, Budidaya dan Pengolahan Pasca Panen. Kanisius, Yogyakarta.

Sari, D. E. dan A. K. Armayanti, 2018, Efek Antifeedant Ekstrak Ageratum conyzoides L. terhadap Spodoptera sp., Jurnal Agrominansia, No. 2, Vol. 3, Hal. 89-95.

Setiawati, W., A. Hasyim, A. Hudayya, dan B. M. Shepard, 2014, Evaluation of Shade Nets and Nuclear Polyhedrosis 
Virus (SeNPV) to Control Spodoptera exigua (Lepidoptera: Noctuidae) on Shallot in Indonesia, Journal Advanced in Agriculture and Botanics Bioflux, No. 1, Vol. 6, Hal. 88-97.

Sitompul, A. F., S. Oemry, dan Y. Pangestinigsih, 2014, Uji Efektifitas
Insektisida Nabati terhadap Mortalitas Leptocorisa acuta Thunberg (Hemiptera : Alydidae) pada Tanaman Padi (Oryza sativa L.) di Rumah Kaca, Jurnal Online Agroteknologi, No. 3, Vol. 2, Hal. 1075-1080. 